\title{
THE ANT CAMPONOTUS (MYRMEPOMIS) SERICEIVENTRIS GUÉRIN AND ITS MIMIC
}

\section{By William Morton Wheeler}

Camponotus (Myrmepomis) sericeiventris, owing to its size, wide distribution and dense covering of silver or golden pubescence, is one of the handsomest and most conspicuous ants of the American tropics. It has not been carefully studied, however, though it was originally described a century $\operatorname{ago}^{1}$ and has since been repeatedly noticed by myrmecologists. When some years ago the huge and unwieldy genus Camponotus was divided into subgenera, sericeiventris, together with several species from the Ethiopian and Malagasy Regions, was assigned by Forel to the subgenus Myrmepomis. Later I transferred all the species, except sericeiventris, to my subgenus Myrmopiromis, thus leaving Myrmepomis as a monotypic group. In 1907 Forel $^{2}$ distinguished a subspecies rex, and published some remarks on its distribution and that of the typical form. On recently revising all the specimens that have been accumulating for many years in my collection and in the Museum of Comparative Zöology, I find that there are several varieties of each of the two forms and that workers of both exhibit a peculiar polymorphism. There are not only major, media and minima phases, but a distinct maxima which has not been described. Its head is decidedly larger and somewhat differently shaped from that of the

${ }^{1}$ As Frormica sericeiventris by Guérin-Méneville (in Duperry, Voyage de le Coquille. Zool. Vol. 2, 1830, p. 205). It was described and figured three years later by Perty (Delectus Anim. Articul. 12, 1833 , p. 134) as Formica cuneata.

${ }^{2}$ Formiciden aus dem Naturhistorischen Museum in Hamburg. II Feil. Mitteil. Naturh. Museum Hamb. 26, 1907, p. 13. 
major and has shining sides. I have seen the females of some of the forms, but the male is still unknown.

The typical sericeiventris, originally described from Rio de Janeiro, is less widely distributed than has been supposed. It occurs in Brazil, Paraguay, Uruguay and portions of the Argentine, but I have seen no specimens from the Guianas or Venezuela. It is recorded also from Peru, Ecuador, Colombia and Mexico, but the specimens in my collection from these countries, like those from Panama and other Central American localities, have more brilliantly colored appressed pubescence and represent a distinct variety which I have called satrapa. I suspect that Forel has identified some of them as belonging to rex. The typical form of this beautiful subspecies occurs in Central America, especially Guatemala, but has varieties in Honduras and Mexico. All the records I have been able to find are cited under the descriptions of the various forms.

Colonies of sericeiventris and rex are fairly populous. They nest in decayed portions of standing tree-trunks some distance above the ground. I have found several such nests, usually in mango or Celtis trees, in Panama, Costa Rica and Guatemala. The workers are very aggressive and the maximæ are able to bite severely. The smaller workers are often seen ascending and descending the trunks of trees even in bright sunlight. Occasionally this ant is introduced into the United States on fruit boats. Mann found specimens of sericeiventris in a restaurant at Palo Alto, California, and I have received two specimens of rex, taken by Mr. F. M. Schott in New York City on a boat from Panama. In both cases the specimens probably arrived as stowaways in bunches of bananas.

Some years ago Dr. J. Bequaert gave me several peculiar Cerambycid beetles which he had taken June 4, 1924, on tree trunks at Prieta, Honduras, in company with workers of $C$. sericeiventris rex var. semirex. The beetles so closely resemble the ants that they may be regarded as highly mimetic. In an article in the present number of Psyche, Dr. W. S. Fisher has described the beetle as Eplophorus velutinus sp. nov., and I have inserted below a photograph made by Dr. F. M. Carpenter (Fig. 2). The beetle's body 
is black, with short golden pubescence on the posterior half of the prothorax and anterior half of the elytra. The latter are distinctly constricted in front of the middle, where they have on each side an oblique ivory yellow and a larger black fascia. The golden pubescence anterior to the constriction is sparse, like that on the prothorax, but the convex posterior portion is covered with dense, longitudinal appressed pubescence of a brilliant golden hue. There is a

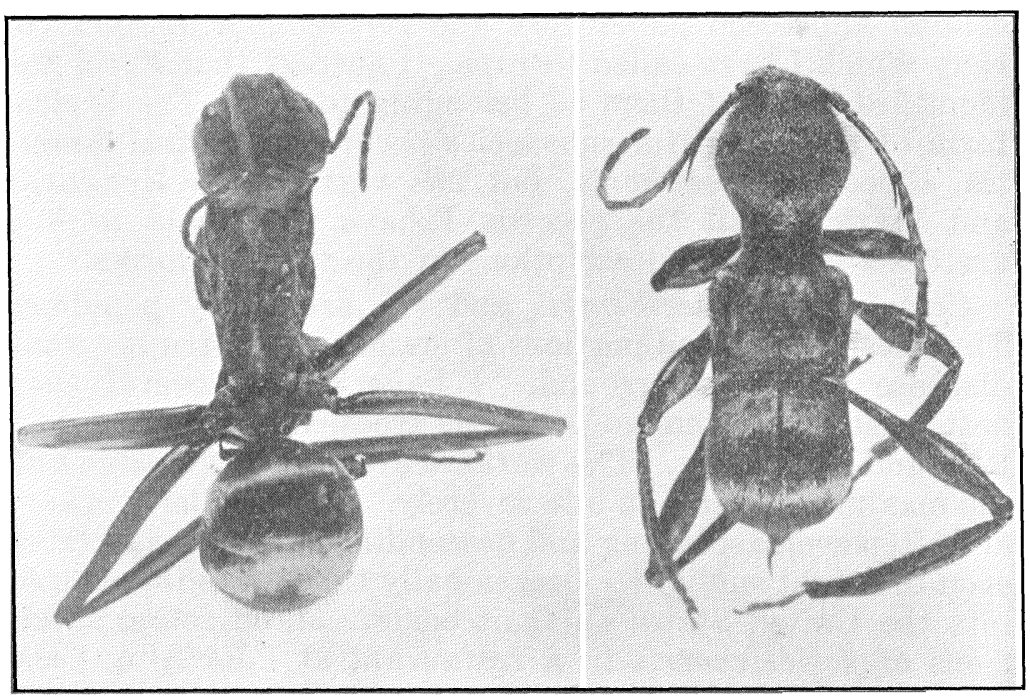

Figures 1 and 2. 1. Camponotus sericeiventris rex var. semirex. 2. Eplophorus velutinus Fisher.

pair of lateral, velvety black spots on the prothorax, and the tibiæ, especially the hind pair are peculiarly flattened as in the ant. The beetle's head and prothorax together represent the ant's head, with the pair of black spots simulating the eyes, and the elongated third joint of the antennæ the scapes; the anterior portion of the elytra resembles the ant's thorax and the posterior portion its gaster. The ivory and black fasciæ give the illusion of the pronounced constriction at the ant's petiole. As in other cases, 
all this striking mimetic resemblance disappears under a high magnification like that of the photographs. (Figs. 1 and 2.)

The literature contains references to several other antmimicking Cerambycids. Belt, ${ }^{1}$ who was one of the first to notice such forms, says that "amongst the longicorn beetles of Chontales, Mallocera spinicollis, Neoclytus Oesopus and Diphyrama singularis Bates, all closely resemble stinging ants when moving about on fallen logs." Bedel $^{2}$ in 1885 described a small longicorn as Pseudomyrmeceon ramalium, taken in Eastern Algeria on the twigs of Quercus Mirbecki D. R. in company with workers of Crematogaster, very probably $S$. scutellaris Oliv., which it closely resembles in size and coloration. Bedel remarks that the beetle's "form, coloration and gait give it, when alive, a singular resemblance to the ants of the genus Crematogaster, and since it is commonly found in their midst, it is easily confounded with them." Our North American fauna also contains a number of Cerambycids, notably species of Clytanthus, Euderces, Cyrtophora and Tillomorpha, which resemble ants in size, shape, coloration and behavior. The resemblance is very striking in two other forms, Cyrtinus pygmæus Haldem., which occurs on dead wood among small ants, such as Lasius americanus Emery, and the Carolinian Michthysoma heterodoxum Lec., which, in life, according to Beutenmüller, extraordinarily resembles small workers of the carpenter ant, Camponotus pennsylvanicus Deg.

The following table may serve in identifying the workers of the various subspecies and varieties of $C$. sericeiventris:

Appressed pubescence on body yellowish gray, or pale golden yellow, at the posterior borders of the gastric segments strongly converging to the mid-dorsal line; head of maxima worker longer than broad, its sides only feebly convex, slightly shining, rather densely and finely punctate; pronotal spines acute, longer than broad in all the worker forms

subsp. sericeiventris Guérin, 2

1 The Naturalist in Nicaragua, London, 1874, p. 315.

${ }^{2}$ Ann. Soc. France, 1885, p. cxxxi. 
Appressed pubescence longer, coarser and more golden, dull ochraceous or brownish, feebly or indistinctly convergent at the posterior borders of the gastric segments; head of maxima as broad as long, with more convex or swollen cheeks, its sides more extensively smooth and shining and only sparsely and superficially punctate; pronotal spines short and blunt even in the small workers subsp. rex Forel, 5

2. Gaster and legs deep reddish.....var. holmgreni var. nov. Gaster and legs black

3. Head of maxima extensively deep red on sides, with rounded lateral borders, the posterior border very deeply excised and the posterior corners narrowed in the major worker; border of petiole much compressed and very sharp; pubescence golden ochraceous, rather sparse on head and thorax.....var. otoquensis var. nov. Sides of head of maxima worker black or only slightly reddish, feebly shining, less deeply excised behind ......4

4. Appressed pubescence on body silvery, often with a slightly golden hue; border of petiole not produced upward in the middle. sericeiventris (typical)

Sides of head of maxima somewhat smoother and more shining; appressed pubescence on body more distinctly and more vividly golden; border of petiole usually produced in the middle as a small blunt tooth

var. satrapa var. nov.

5. Pubescence brilliantly and deeply golden, very dense on the thorax and posterior portion of the head, present even on the coxae and petiole....subsp. rex (typical)

Pubescence less developed, except on the gaster.

6. Pubescence dull ochraceous, dense on the pronotum but poorly developed on the sides of the thorax; sides of head of maxima worker red.

var. cualatensis var. nov.

Pubescence on gaster more deeply and more vividly golden, more as in the typical rex 
7. Pubescence on head, thorax and petiole bright golden yellow but much shorter than in typical rex

var. semirex var. nov.

Sides of thorax almost or quite devoid of pubescence $\ldots . .8$

8. Pubescence dull, golden ochraceous present on vertex, pronotum and petiole........... var. zacapensis var. nov.

Pubescence absent on head, thorax and petiole, on gaster golden ochraceous var. quiriguensis var. nov.

\section{Camponotus (Myrmepomis) sericeiventris Guérin}

Worker maxima. Length $15-16.5 \mathrm{~mm}$.; head 5-5.7 mm. long; 4.5-5.2 mm. wide; hind tibia $5.6 \mathrm{~mm}$.

Head with rather straight sides, without swollen cheeks; subopaque except the sides and gular surface which are reddish and shining, but covered with minute punctures; antennal funiculi dark brown. Spines of pronotum rather sharp, longer than broad. Superior border of petiole sharp, entire and broadly rounded, angulate on the sides. Appressed pubescence not very abundant and not completely concealing the integument on the head, meso-and epinotum, petiole and sides of pronotum; denser on the gaster where it strongly converges at the posterior borders of the segments. Hairs rather long, black, often with white tips; posterior borders of gastric segments with whitish or yellowish hairs.

Workers major, media and minor. Length 7-13 mm.

Resembling the maxima, except in the smaller head and longer and more acute pronotal spines.

Female. Length 17-19 mm.; hind tibia $5 \mathrm{~mm}$; fore wing $17 \mathrm{~mm}$.

Head smaller and narrower than in the worker maxima, with narrower posterior corners and less convex sides, nearly as broad in front as behind. Color and sculpture similar, but in some specimens the anterior half as well as the sides is red. Pronotal spines reduced to two small teeth. 
Mesonotum and scutellum smooth and shining, often reddish, the former as broad as long. Epinotum with short, rounded base and long sloping declivity. Petiolar border notched in the middle, its angulate corners more pronounced and acuminate than in the workers. Pubescence and pilosity similar, short on head and thorax, absent on anterior portion of pronotum and on the scutellum. Wings distinctly brownish, with brown veins bordered with darker brown.

Brazil: Rio de Janeiro, type-locality (Thayer Exped.; J. C. Bradley; C. O. Lovén) ; Abuna, Rio Madeira (Mann and Baker); Sao Paulo (H. von Ihering); Island of Sao Sebastiao; Raiz da Serra; Jundiahy; Bauru and Piracicaba, in the state of Sao Paulo (H. Luederwaldt); Rio Negro, Amazonas (Ducke) ; Rio Doce, Espiritu Santo (M. Caullery) ; Sao Leopoldo (J. W. Stahl) ; Rio Grande do Sul (C. Lindman) ; Blumenau; Taquara, Santa Catharina (H. von Ihering).

\section{Uruguay (teste Forel).}

Paraguay: Encarnacion (J. C. Bradley) ; San Bernardino (Fiebrig); Aregua (Zürcher).

Argentina: Chaco, Corrientes and Misiones (C. Berg); Misiones (Mme. von Steiger).

Var. satrapa var. nov.

Worker maxima. Length $14-15 \mathrm{~mm}$.; head $4.8 \mathrm{~mm}$. long, $4.4 \mathrm{~mm}$. wide; hind tibia $5 \mathrm{~mm}$.

Very similar to the typical sericeiventris but somewhat smaller and with more brilliant, golden pubescence, longer and denser on the vertex, thorax and petiole; hairs blackish at base, with yellow tips. Sides of head blackish or dark brown, smoother and more shining, their punctures sparser. Border of petiole usually produced or subdentate in the middle.

Workers maior, media and minor. Length 6-13 mm.

Very similar to the corresponding phases of the typical 
sericeiventris but the pubescence is more golden, as in the maxima, and the petiolar border is usually more or less distinctly subdentate in the middle.

Female. Length about $16 \mathrm{~mm}$.

Closely resembling the female of the typical sericeiventris but with entirely black head and thorax, the former more deeply excised behind and with much smoother and more shining sides, the petiolar border without a median notch and with less produced lateral corners. Wing membranes distinctly more deeply infuscated. Appressed pubescence more golden as in the worker satrapa, and the convergence of the pubescence on the second and third gastric segments even more pronounced than in the typical sericeiventris.

I have seen specimens of this form, which has been confused with the true sericeiventris, from nearly all the following localities:

Panama: Barro Colorado Island, type locality (Wheeler; N. Banks; P. Rau; W. C. Allee; P. Haskins) ; Rio Chenillo (Wheeler) ; David (C. Richter).

Colombia: (Lindig); (Tischbein; Forel); Antioquia (Nisser; Kraemer) ; Puerto de los Pobres, Antioquia (O. Fuhrmann).

Ecuador: Santo Domingo de los Colorados and between San Nicolas and Guanasilla (P. Rivet).

Peru: Santa Ana, 3,000 ft. (Yale Peruv. Exped.) ; Upper Pachitea (J. C. Bradley).

Brazil: Puerto America, Rio Putumayo (J. C. Bradley).

Costa Rica: (Tonduz); Port Limon (Wheeler; F. C. Paulmier); Turrucares (P. P. Calvert); Turrucares and Hamburg Farm (C. W. Dodge); Rio Raventazon, Santa Clara (P. Biolley) ; near San Jose (H. Schmidt).

Honduras: Ceiba, Lombardia; Carmelina, Progresso, Tela (W. M. Mann).

Var. holmgreni var. nov.

Worker major. Length $12 \mathrm{~mm}$.

Very similar to the typical sericeiventris, but the funiculi, corners of the head, the gaster and legs are deep red. 
The appressed pubescence is somewhat coarser and more yellowish and on the head and thorax somewhat longer than in the typical form of the species.

Worker minor. Length about $8 \mathrm{~mm}$.

Colored like the worker major but the red coloration is more extensive, involving also the scapes, gula, sides of pronotum, petiole and coxæ.

Two major and a single minor worker taken by Dr. N. Holmgren at Tuiche, Bolivia and belonging to the Stockholm Museum.

Var. otoquensis var. nov.

Worker maxima. Length 13-14 mm.; head $4.5 \mathrm{~mm}$. long, $4 \mathrm{~mm}$. wide; hind tibia $5 \mathrm{~mm}$.

Head narrowed behind at the posterior corners, which are narrow and very prominent; posterior border deeply concave; sides extensively and gula deep red, smooth and shining, with very fine, superficial punctures. Pronotal spines acute. Upper border of petiole strongly compressed, in some specimens irregular in outline, in others deeply excised in the middle. Appressed pubescence very dull yellow, shorter and less abundant on head, thorax and petiole than in the var. satrapa. Legs somewhat brownish. Workers major and media. Length 10-12 $\mathrm{mm}$.

Like the maxima in color and pubescence, except that the sides of the head are deep brown or black.

Described from a series of workers taken by myself Nov. 19, 1911 from a nest in the decayed portion of a large mango tree on Otoque Island, about 30 miles from the City of Panama.

\section{Subsp. rex Forel.}

Worker maxima. Length $13-14 \mathrm{~mm}$; head $4.5 \mathrm{~mm}$. long and $4.5 \mathrm{~mm}$. broad; hind tibia $5.2 \mathrm{~mm}$.

Differing from the maxima worker of sericeiventris in its somewhat more robust stature, in having the head as broad as long, with more convex, or swollen cheeks, the 
pronotum with short, very blunt spines, the meso- and metanotum less strongly compressed above, the petiole with blunt, broadly rounded superior border and more obtuse lateral angles, the flattened tibiæ somewhat broader. The appressed pubescence is coarser, longer and denser, deep golden yellow, feebly or indistinctly converging to the middorsal line at the posterior borders of the gastric segments. Hairs abundant, on the head and thorax, black with deep fulvous tips, on the gaster fulvous throughout. Head and mandibles deep red, vertex blackish, sides, clypeus and gula shining and very finely punctate, the posterior corners with several short impressed line-like punctures.

Workers major, media and minor. Length 8-12 mm.

Resembling the maxima, except in having the head smaller and black throughout, the appressed pubescence, however, even more abundant, covering the thorax, coxæ, petiole and posterior half of the head as well as the gaster. Pronotal spines short and blunt, petiole with obtuse superior border as in the maxima.

Female (undescribed). Length $16-17 \mathrm{~mm}$.; fore wing 15.5 $\mathrm{mm}$.

Resembling the worker maxima, but head slightly longer than broad, subtrapezoidal, with rather straight sides and feebly excavated posterior border; the sides, clypeus and gula smooth and shining, deep red, as are also the mandibles. Pronotum with small blunt projections instead of the spines. Petiole shaped as in the maxima. Pubescence, especially on the head and thorax somewhat shorter. Scutellum and anterior portion of mesonotum smooth and shining, without pubescence. Wings colored as in the typical sericeiventris.

Costa Rica: Pacuarito, type-locality (W. Paap).

Guatemala: Champerico, Corinto and San Benito (R. Paessler) ; Retaluleu (Stoll) ; Patulul (Wheeler).

Mexico: La Zacualpa, Chiapas (A. Petrunkevitch). Santa Lucrezia, Vera Cruz (F. Knab); Cordova; Remutadero, Cameron and Mirador, Vera Cruz (E. Skwarra). 
Var. semirex var. nov.

Workers media and minor. Length 8-11 $\mathrm{mm}$.

Very similar to rex, but the appressed pubescence is almost lacking on the thorax and petiole, though well developed on the head and dorsal surface of the pronotum. The pronotal spines are very short and obtuse, the petiolar scale with blunt, broadly rounded border as in rex.

Described from five specimens taken by Dr. J. Bequaert at Corocito, Honduras.

Var. cualatensis var. nov.

Worker maxima. Length $12-14 \mathrm{~mm}$.; head $5 \mathrm{~mm} . \mathrm{x} 5 \mathrm{~mm}$.; hind tibia $5.2 \mathrm{~mm}$.

Head entirely red, shining, especially on the sides and clypeus; mandibles black. Pronotal spines as in rex. Petiole with sharp, compressed dorsal border, seen from behind broadly rounded, entire, with pronounced lateral angles. Appressed pubescence dull, rather ochraceous yellow, less abundant on the sides of the thorax than in rex. Hairs abundant, but distinctly shorter, especially on the epinotum and gaster, fulvous yellow. Legs somewhat reddish. Workers major, media and minor. Length 8-12 $\mathrm{mm}$.

Like the maxima, except for the smaller head. This is more or less reddish in the major but black in the smaller phases. Meso- and epinotum strongly compressed dorsally, as is also the border of the petiolar scale.

Mexico: Cualata, Colima, type-locality (C. H. T. Townsend) ; Jalapa (S. F. Rangel) ; Guadalajara (J. F. McClendon; M. Diguet).

Var. zacapensis var. nov.

Worker maxima. Length 13-15 mm.; head 5 x $5 \mathrm{~mm}$.; hind tibia $5.5 \mathrm{~mm}$.

Resembling the maxima of cualatensis but with the head black. Pronotal spines broad and obtuse, somewhat flattened. Dorsal border of petiolar scale blunt, not compressed, 
seen from behind broadly rounded and entire. Appressed pubescence dull ochraceous, slightly brighter on the gaster than in cualatensis, very short and feebly developed on the vertex, long and more conspicuous on the middle of the pronotum, shorter on the dorsum of the mesonotum, absent on the pleuræ and coxæ, very short on the posterior surface of the petiole. Hairs short, especially on the gaster where they are mostly orange yellow; on the head and thorax with black bases and orange tips.

Workers major, media and minor. Length 8-12 mm.

Like the maxima, but head smaller and without shining sides, gula and clypeus; in the smaller individuals with nearly straight posterior border. Pronotal spines very obtuse as in the maxima; meso- and epinotum more strongly compressed above. Hairs similar but less abundant on the head and thorax.

Described from numerous specimens which I took Dec. 14,1911 , from a flourishing colony nesting in the decayed wood of a large Celtis tree in the very arid country around Zacapa, Guatemala. There are also specimens in the $\mathrm{Mu}-$ seum of Comparative Zoology from Portilla Grande, Honduras (R. E. Stadelmann).

Var. quiriguensis var. nov.

Worker maxima. Length $12-13 \mathrm{~mm}$; head 4.5 x $4.5 \mathrm{~mm}$.; hind tibia $5 \mathrm{~mm}$.

Smaller than the preceding variety, but the head very similar, black with somewhat less shining sides. Pronotal spines and petiolar node similar. Appressed pubescence on the gaster dense and brilliant golden as in the typical rex, but almost absent on the head and thorax, there being only some short dilute ochraceous pubescence on the vertex and dorsum of the pronotum. Hairs similar, but less abundant on the head and thorax and somewhat longer on the gaster, though not as long as in rex. 
Workers major, media and minor. Length 8-11 mm.

Very similar to the maxima, except for the smaller head and opaque cheeks and clypeus. Spines of pronotum, though blunt, more slender than in the var. zacapensis.

Described from several workers taken by myself Jan. 13, 1912 , running on the trunk of a recently felled tree in the banana plantations near Quirigua, Guatemala (type-locality). I possess specimens also from the following localities in the same republic: Polochic River and Cacao, Trece Aguas, Alta Vera Paz (Barber and Schwarz), Livingston (H. S. Barber), Los Amates, Baja Vera Paz and Sanarola (Kellerman), and from Belize, British Honduras. 

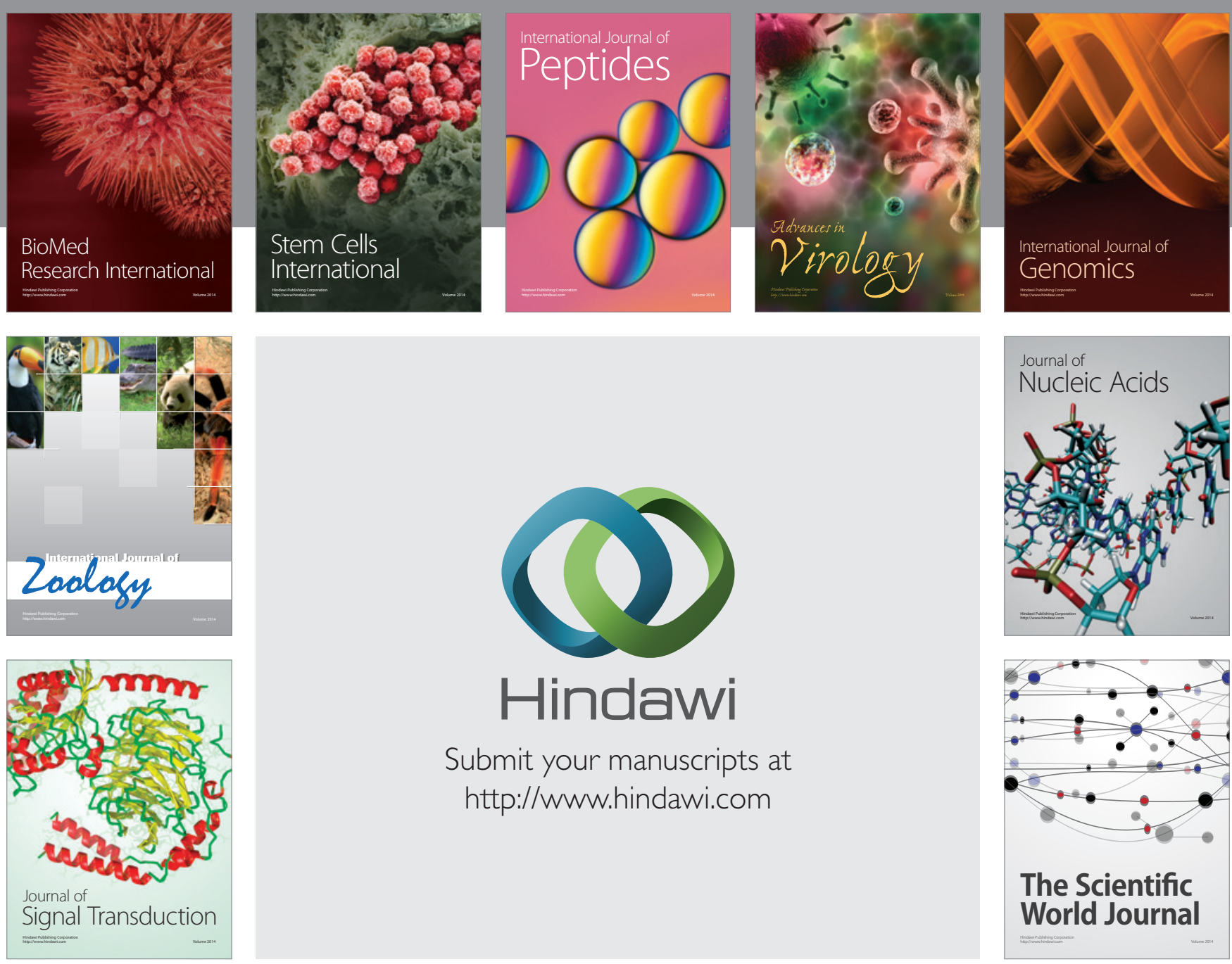

Submit your manuscripts at

http://www.hindawi.com
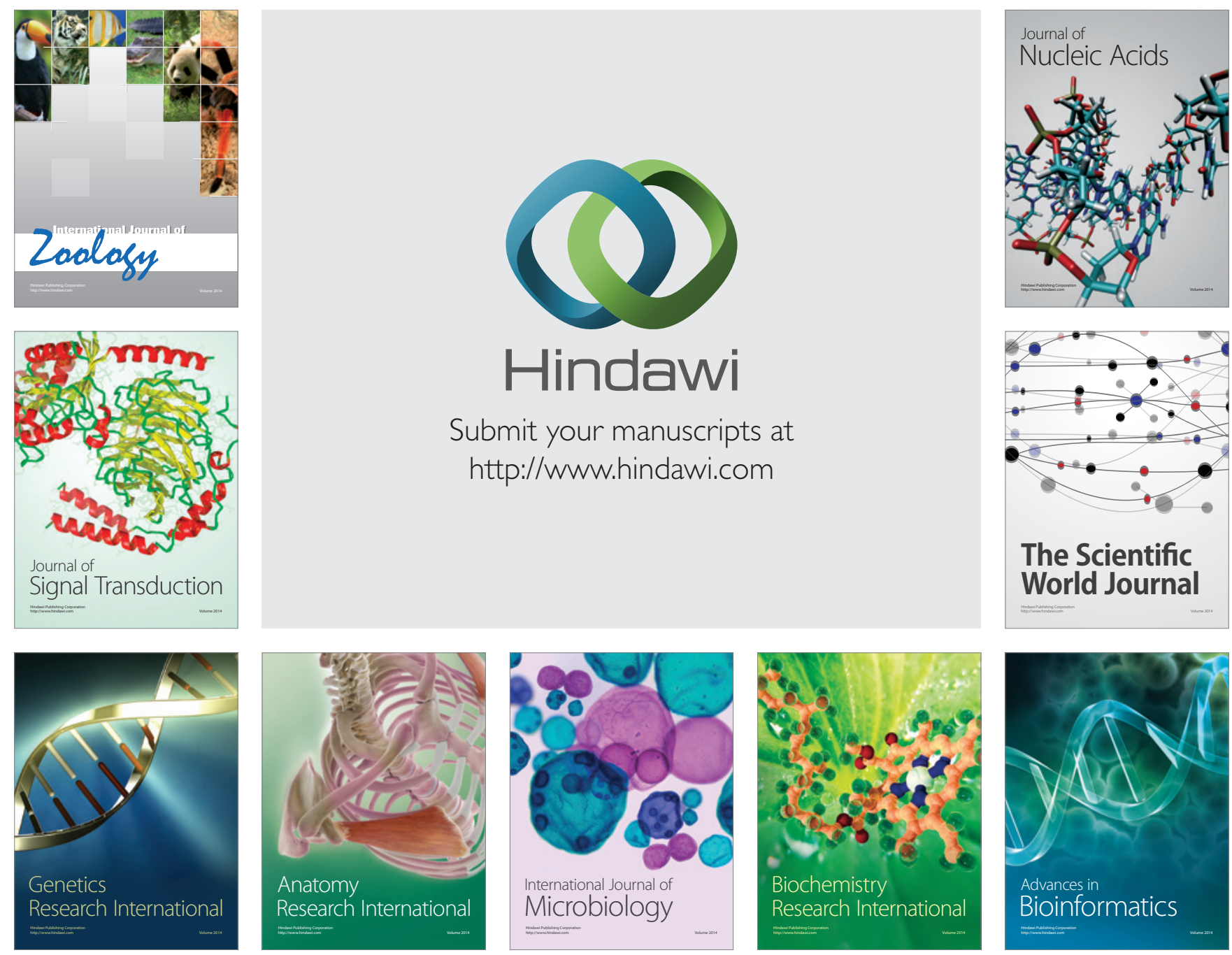

The Scientific World Journal
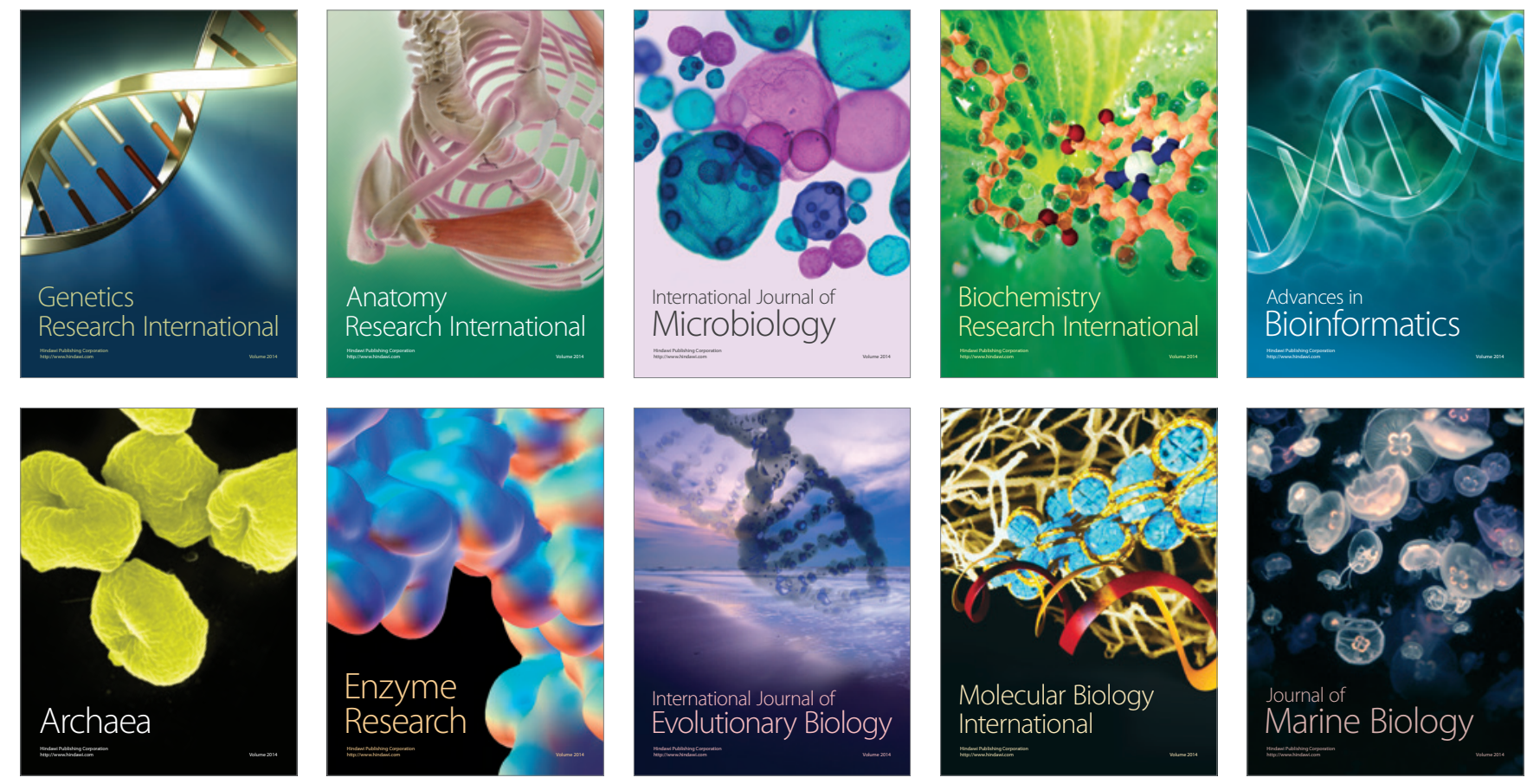